\title{
Correction: Studholme et al., Draft Genome Sequences of Xanthomonas sacchari and Two Banana-Associated Xanthomonads Reveal Insights into the Xanthomonas Group 1 clade. Genes 2011, 2, 1050-1065.
}

\section{David J Studholme ${ }^{1, *}$, Arthur Wasukira ${ }^{1,2}$, Konrad Paszkiewicz ${ }^{1}$, Valente Aritua ${ }^{2,3, \dagger}$, Richard Thwaites ${ }^{3}$, Julian Smith ${ }^{3}$ and Murray Grant ${ }^{1}$}

1 Biosciences, University of Exeter, Geoffrey Pope Building, Stocker Road, Exeter, EX4 4QD, UK;

E-Mails: awasukira@gmail.com (A.W); k.h.paszkiewicz@exeter.ac.uk (K.P.);

m.r.grant@exeter.ac.uk (M.G.)

2 National Crops Resources Research Institute (NaCRRI), P.O. Box 7084, Kampala, Uganda;

E-Mail: arituavalentine@yahoo.com (V.A.)

3 The Food and Environment Research Agency, Sand Hutton, York, YO41 1LZ, UK;

E-Mails: richard.thwaites@fera.gsi.gov.uk (R.T.); julian.smith@fera.gsi.gov.uk (J.S.)

$\dagger$ Current address: Department of Plant Pathology, University of Florida, Citrus Research and Education Center, 700 Experiment Station Road, Lake Alfred 33850, USA

* Author to whom correspondence should be addressed; E-Mail: d.j.studholme@exeter.ac.uk.

Received: 10 January 2012 / Accepted: 10 January 2012 / Published: 11 January 2012

Following publication of our article [1], we found errors in analyses performed by the corresponding author (DJS) related to the phylogenetic relationship between Xylella species and the other xanthomonads. These errors do not make any difference to the main findings and conclusions reported in our paper. For example, the phylogenetic positions of NCPPB1131, NCPPB1132 and NCPPB4393 within the Group 1 Xanthomonas species are unaffected. However, we wish to apologize to the authors of a previous work [2] for creating any negative impression on the quality of their phylogenetic analyses and to take this opportunity to rectify the errors. The details of the errors are listed below:

(1) In section 2.3 of our paper [1], we wrote "for three of the genes (efp, glnA and gyrB) we were unable to build valid multiple sequence alignments because of a lack of orthologues with detectable nucleotide sequence similarity. For example, blastn searches against the NCBI 
non-redundant nucleotide database, using X. albilineans gyrB (XALc_0004) as the query, yielded no significant matches in Xylella species". This statement was misleading as there are in fact orthologues of efp, glnA and $g y r B$ in species of both Xanthomonas and Xylella.

(2) In section 2.3 of our paper [1], we wrote "Second, Pieretti's analysis ... appears to be partly based on alignments of non-orthologous gene sequences (e.g. their gyrB sequences are not orthologous between Xylella and Xanthomonas species)". This statement was incorrect; there is no evidence to suggest that any non-orthologous sequences were aligned in the phylogenetic analyses performed by Pieretti et al. [2].

(3) In section 2.4 of our paper [1] we wrote "the last common ancestor of X. albilineans and Xylella fastidiosa was also the ancestor of the other xanthomonads". In fact it remains unanswered whether or not Xylella forms a monophyletic group with X. albilineans and the other Group 1 Xanthomonas species. Therefore, it would be more appropriate to write that the last common ancestor of $X$. albilineans and Xylella fastidiosa may have been also the ancestor of the other xanthomonads.

\section{Acknowledgements}

DJS wishes to thank Dr Philippe Rott for helpful discussion and for drawing attention to the errors.

\section{References}

1. Studholme, D.J.; Wasukira, A.; Paszkiewicz, K.; Aritua, V.; Thwaites, R.; Smith, J.; Grant, M. Draft Genome Sequences of Xanthomonas sacchari and Two Banana-Associated Xanthomonads Reveal Insights into the Xanthomonas Group 1 Clade. Genes 2011, 2, 1050-1065.

2. Pieretti, I.; Royer, M.; Barbe, V.; Carrere, S.; Koebnik, R.; Cociancich, S.; Couloux, A.; Darrasse, A.; Gouzy, J.; Jacques, M.A.; Lauber, E.; Manceau, C.; Mangenot, S.; Poussier, S.; Segurens, B.; Szurek, B.; Verdier, V.; Arlat, M.; Rott, P. The complete genome sequence of Xanthomonas albilineans provides new insights into the reductive genome evolution of the xylem-limited Xanthomonadaceae. BMC Genomics 2009, 10, 616.

(C) 2012 by the authors; licensee MDPI, Basel, Switzerland. This article is an open access article distributed under the terms and conditions of the Creative Commons Attribution license (http://creativecommons.org/licenses/by/3.0/). 